\title{
Challenges Affecting Educational Research in Delta State, Nigeria
}

\author{
Rowell Ubogu ${ }^{1}$ \\ ${ }^{1}$ Institute of Education, Delta State University [E-mail: istinctprint1@gmail.com]
}

\begin{abstract}
This study investigated the factors inhibiting the conduct and uptake of educational research in Nigeria with specific reference to Delta State. Data were collected using a self-administered questionnaire from forty-two (42) academic staffs drawn from three universities and three Colleges of Education in the state. The data was analysed using descriptive statistics. Two hypotheses on factors affecting research were tested at the level of confidence $p .=.05$ using the student$\mathrm{t}$ test. A range of managerial and methodological factors were identified as affecting the conduct and uptake of research in the country. These respectively included absence of a clear national development philosophy and adequate funding for research and gaps in methodological competence and research integrity on the part of educational researchers. These findings are cross-referenced with related literature after which conclusions are drawn and recommendations are made.
\end{abstract}

Keywords: Research for development; Knowledge management; Policy research.

\section{$1 \quad$ Introduction}

The inquisitive nature of people has always led them into adventure with a bid to uncover grounds yet unknown to them. Udegbe and Odigwe (2008) posit that people have always searched for facts yet unknown to them, and when answers to such facts are found, the target is to solve identified problems, hasten progress and development, promote advancement of knowledge, increase understanding of new phenomena and raise the standard of living (Nworgu, 1991). This intrinsic nature of people has not only changed their way of life but has also made them pass through various stages of development over time. In the area of education, educational research is a veritable tool for both educational development and national development. For example, Bajah (1990) sees research as the most important tool for advancing knowledge, for prompting progress, which enables people to accomplish their goals and resolve their conflicts. 
Educational research can be regarded as an activity designed to evolve theories guiding the principle and practice of education. It attempts to use the methods and procedures made popular in the physical sciences to find answers to problems facing the education industry (Jimoh, 1998). Generally, educational research involves the systematic application of scientific method to the study of educational problems; the search and application of this knowledge for development of new and improved products, services and industrial processes of capital development which have in recent times emerged to occupy the center stage in the activities of the western universities (Ubogu, 2008).

In fact, research has become one of the most enduring and effective means of boosting sustainable education and economic development and re-enforcing competitiveness in the face of rapid growth taking place among industries, countries and peoples in the world (Bako, 2005). To this end, it could be deduced that educational research encompasses many different studies all of which attempt to better understand and improve the learning and educational process, as well as the nation (Orluwene \& Opara, 2006).

In advanced countries, research has come to assume an indispensable status in national development (Nworgu, 1991). In the less developed countries like Nigeria, however, the utilization of research in policy making and development is low and in some cases entirely nonexistent. Although many researches are conducted and their findings published each year, much of this research is not informing policy and practice in the country's pursuit of development. This study delved into this anomaly. Although the poor uptake of research findings could be the consequence of a range of factors, the study focused on managerial and methodological factors as possible inhibitors of uptake of research findings. Therefore, the study undertook to verify two hypotheses that: 1) Academic integrity issues (i.e. academic scandal, and plagiarism) does not significantly constitute a major challenge to uptake of educational research findings in Nigeria; and 2) Scientific methods employed does not significantly constitute a major challenge to educational research findings in Nigeria.

\section{$2 \quad$ Methodology}

This study adopts a survey design, and the population for the study consists of 150 Lecturers in Tertiary Institutions in Delta State. The sample is made up of 42 lecturers from 6 Tertiary institutions (3 Universities, i.e. Federal University of Petroleum Resources (FUPRE), Delta State University, Abraka and Novena University, Kwale) and (3 Colleges of Education, i.e. Colleges of Education, Agbor, Colleges of Education, Warri and Colleges of Physical Health Education, Mosogar) all in Delta State based on the number of questionnaire retrieved using 
a systematic random sampling technique. Data was collected using a selfadministered questionnaire titled "Challenge of Educational Research in Higher Institutions" (CERFHI), which was designed by the researcher. The Instrument was validated by three professionals in educational administration from the three Universities that were involved in the study. A four point Likert scale of (SA) Strongly Agree (4 points), (A) Agree (3 points), (D) Disagree (2points) and (SO) Strongly Disagree was used in the questionnaire. An arbitrary, but logical neutral point of 2.5 forming the average was calculated for each item, signifying that all variables below 2.5 are negative (Disagree) and all variables above 2.5 mean mark are considered positive (Agree).

\section{$3 \quad$ Findings}

The findings on the factors inhibiting the uptake of research findings are shown in Tables 1 and 2. Table 1 shows the mean rating of the respondents all scoring above the average 2.5 mean mark, the indicating that the above areas were issues that constitute challenges of Educational Research Findings in Nigeria.

On the other hand, Table 2 reveals the mean rating of the respondents all scoring above the average 2.5 mean mark, thus indicating that the areas enumerated were ethical issues challenging educational research findings in the area. 
Table 1: Managerial challenges inhibiting uptake of research

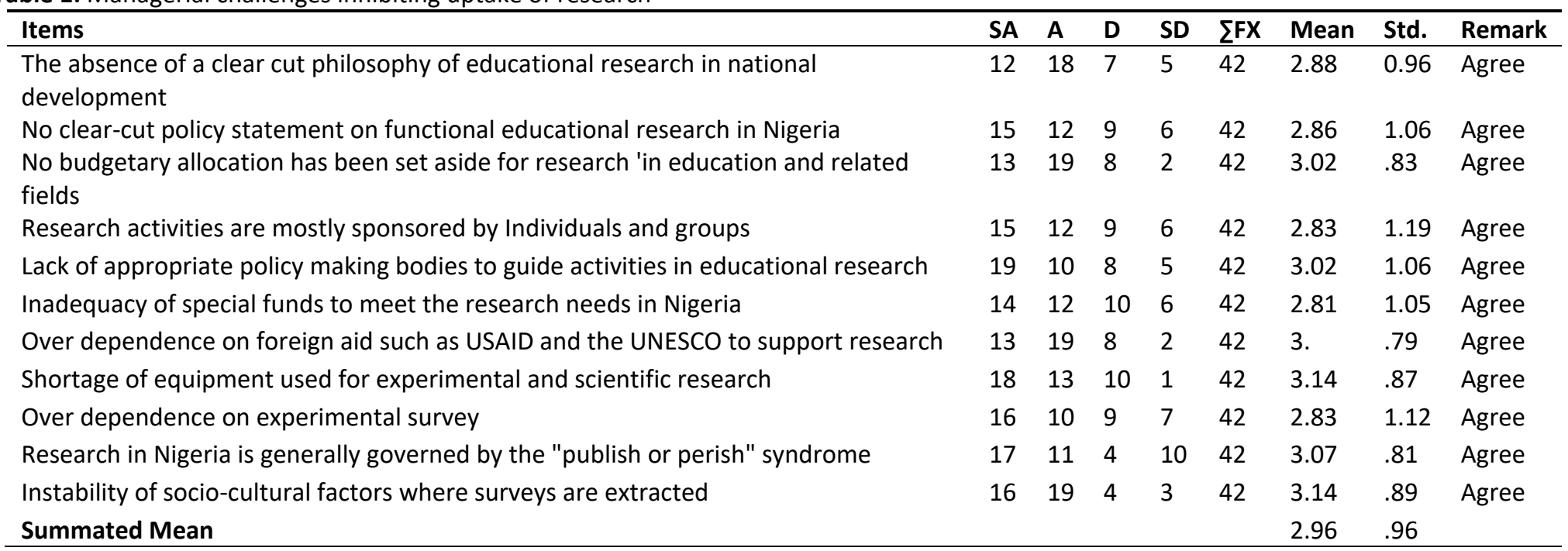

Table 2: Methodological challenges inhibiting uptake of research

\begin{tabular}{|c|c|c|c|c|c|c|c|c|}
\hline Items & SA & A & D & SD & $\sum \mathrm{FX}$ & $\mathrm{X}=$ Mean & Std. & Remark \\
\hline The lack of academic integrity pose treat to educational research findings & 17 & 12 & 9 & 4 & 42 & 3 & 1.01 & Agree \\
\hline Poor study design pose treat to educational research findings & 15 & 14 & 11 & 2 & 42 & 3.05 & .9 & Agree \\
\hline Misinterpretation of $p$-values pose treat to educational research findings & 18 & 10 & 13 & 1 & 42 & 3.07 & .92 & Agree \\
\hline Research procedure pose treat to educational research findings & 12 & 19 & 5 & 6 & 42 & 2.88 & .99 & Agree \\
\hline
\end{tabular}


The hypothesis that "Academic integrity issues (i.e. academic scandal, and plagiarism) does not significantly constitute a major challenge to uptake of educational research findings in Nigeria" was tested using the Student-t test. The findings are summarized in Table 3.

Table 3: Student t- test for hypothesis one

\begin{tabular}{llllllll}
\hline & N & Mean & SD & DF & t-calculated & t-critical & Decision \\
\hline $\begin{array}{l}\text { Academic } \\
\text { integrity issues }\end{array}$ & 42 & 2.91 & 1.07 & 41 & 23.72 & 1.96 & $\begin{array}{l}\text { Reject } \\
\text { hypothesis } \\
\text { one }\end{array}$ \\
$\begin{array}{l}\text { Effectiveness of } 42 \\
\begin{array}{l}\text { Education } \\
\text { Research }\end{array}\end{array}$ & 3.02 & 1.01 & 41 & & & \\
\hline
\end{tabular}

The results of the verification of the second hypothesis (i.e. "Scientific methods employed does not significantly constitute a major challenge to educational research findings in Nigeria") are shown in Table 2.

Table 4: T-test for hypothesis two.

\begin{tabular}{llllllll}
\hline & N & Mean & SD & DF & t-calculated & t-critical & Decision \\
\hline $\begin{array}{l}\text { Scientific methods } \\
\text { employed }\end{array}$ & 3.17 & 1.07 & 41 & 10.23 & 1.96 & $\begin{array}{l}\text { Reject } \\
\text { hypothesis } \\
\text { two }\end{array}$ \\
$\begin{array}{l}\text { Effectiveness of } \\
\begin{array}{l}\text { Education Research } \\
\text { 4 }\end{array}\end{array}$ & 3.24 & 1.01 & 41 & & & \\
\hline
\end{tabular}

As shown in the table above the calculated t value of 10.23 is greater than the critical $t$ value of 1.96. Hence, the null hypothesis is rejected while the alternative is accepted. This shows that Scientific methods employed constitute a major Challenge of Educational Research Findings in Higher Institutions in Nigeria.

\section{Discussion, Conclusion and Recommendations}

The research presented above, revealed that the absence of a clear cut philosophy of educational research in national development, the lack of clear-cut policy statement on functional educational research in Nigeria, lack of budgetary allocation set aside for research in education and related fields, Research activities mostly sponsored by individuals and groups, Lack of appropriate policy making bodies to guide activities in the area of educational research, Inadequacy of special funds to meet the research needs in Nigeria, Over dependence on foreign aid such as USAID and the UNESCO to support research, shortage of 
equipment used for experimental and scientific research, Over dependence on experimental survey which are less demanding and are the common types of research in Nigeria', over emphasis' of the general "publish or perish" syndrome by researchers in Nigeria, and the Instability of socio-cultural factors distinct to the Nigerian society from where surveys are extracted constitute challenges of educational research findings in Nigeria. These findings infirmed the opinion of Udegbe and Odigwe (2008) who lamented that lack of fund, "publish or perish syndrome", societal believe among other challenges possess treat to educational research findings.

In fact, US funded educational research evaluation has led to many valid useful. Models of pedagogy (Darling Hammond, 1997), to policy commitments in support of research linked to educational improvement and to advances to our understanding of how of how people learn. However, the situation is different in Nigeria were funded research programs and projects have not resulted in pervasive widely accepted, sustainable improvement; or in supportive interplay among researchers, schools, families, employers, and communities (Ubogu, 2008).

Furthermore, it was also revealed that the lack of academic Integrity pose, poor study design misinterpretation of $\mathrm{p}$-values, the research procedure in itself and the fact that research are being conducted for selfish reasons rather than for pure research purposes all poses treat or rather constitute the challenge of education research findings in Nigeria. The findings supports Umoru (2010) who established that poor grasp of critical methods of data analysis and also research procedure are among other factors undermines of research results.

In addition it was discovered that Academic integrity issues (academic scandal, and plagiarism) and Scientific methods employed constitute a major Challenge of Educational "Research Findings in Higher Institutions in Nigeria. This finding is In support of previous studies of Labaree (1998), Willinsky (2001) and Chiekem (2008) who reported among other findings, that scientific quality or method of educational research is usually poor. That is ethical issues in educational research are not put into consideration when carrying out research in our higher institution. Thus, educational research findings cannot yields useful results and as such cannot be utilized because they cannot be relied upon.

The essence of educational research in a developing country like Nigeria cannot overemphasize. It is only through such medium can the countries go from where she is to where she wants to be. Therefore researchers have a great responsibility to exercise care in carrying out research abiding by the ethics of research as highlighted above. This paper therefore is a clarion call for all stake holders (government and private) involved in educational research to keep a keen eye for any abnormalities in Educational Research Findings in Higher institutions in Nigeria.

Arising from the findings of this paper it is recommended that; 
1. A modification should be made in the current promotion polity publish or perish syndrome. This will help to eliminate those negative impacts that constitute poor quality research. The implication is that any research that is carefully carried out without considering the time the conference will hold or the next volume of the journal will be produce will actually be a quality one.

2. Researchers should ensure that all data used for analysts is valid and usable for the purpose of the research.

3. The practice of conducting research for the purpose of acquiring higher degrees by students and promotions for teachers in higher educational institutions should be discouraged and be linked to national research priorities and goals. In fact, the quality of educational research and evaluation in our institutions should be enhanced through increased funding by government.

4. Annual Educational budget should be increased to cater for Educational Research.

5. Research should be conducted primarily for the solution of significant problems of a theoretical and applied nature.

\section{References}

Bajah, S. T. (1990). Direction of Research in Science, Technology and Mathematics Education in Nigeria. STAN Annual Conference Proceedings (31st) pg. 123-135.

Bako, S. (2005). Globalization and African Universities: Towards an Equitable Production of World Knowledge Economics, Paper presented for CODESRIA globalization studies network, (second international conference on globalization; overcoming exclusion, strengthening in conclusion, 29th to 31st August, Dakar, Senegal.

Chiekem, E. (2008). Assessment of users and researchers perception of educational research and evaluation for national development, Nigeria Journal of Educational Research-Evaluation.8 (1), 40-46.

Darling Hammond, L. (1997). Teachers and teaching. Testing policy hypotheses from a national commission report, Educational Researchers. 27(1), 5-15.

Jimoh, S. A. (1998). Educational Research in Nigeria: Some Local Forces Inhibiting Progress, and the Way Forward; www.unilorin.edu.ng/journals/education/ije/sept 1998.

Labaree, D.F. (1998). Educati6nal Researchers: living with a lesser form of knowledge. Educational Researchers, 27(8), 4-12.

Nworgu, B. G. (1989). Educational Research: Basics, Issues and Methodology. Ibadan: Wisdom Publishers Limited. 
Orluwene, G. W., Opara, I. M. (2006). Utilization of Educational Research Findings in Nigeria: Implication for National Development. Nigerian Journal of Educational Research and Evaluation. 8(2), 27-35.

Ubogu, R., (2008). Funding of Educational Research and Evaluation for National development. Nigerian Journal of Educational Research and Evaluation. 8 (2), 19-26.

Udegbe, G. I., Odigwe, E. E., (2008). Challenges of educational research and evaluation in Nigeria: The Way Out. Nigerian Journal of Educational Research and Evaluation. 8(2), 46-53.

Umoru, T. A. (2005). Basic research methods. Competencies and application, Lokoja: Onaivi Publishers Ltd.

Umoru, T. A. (2010). Analysis of factors undermining the utilization of research results in Business Education. Business Education Journal. 7(2), 70-76.

Willinsky, J. (2001). The strategic educational program and the public value of research. Educational Researcher. 30(1), 5-14. 